\title{
INTERNAL MODEL FOR IFRS 9 - EXPECTED CREDIT LOSSES CALCULATION
}

This article explores and analyzes the implementation problem of International Financial Reporting Standard 9 (IFRS 9) which is in use from 1 January 2018. IFRS 9 is most relevant for financial institutions, but also for all business subjects with a significant share of financial assets in their Balance sheet. The main objective of this article is the implementation of new impairment model for financial instruments, which is measurable through Expected Credit Losses (ECL). The use of this model is in correlation with a credit risk of the company for which it is necessary to determine basic variables of the model: Exposure at Default (EAD), Loss Given Default (LGD) and Probability of Default (PD). Basel legislation could be used for LGD calculation while PD calculation is based on specific methodology with two different solutions. In the first option, PD is taken as an external data from reliable rating agencies. When there is no external rating, an internal model for PD calculation has to be created. In order to develop an internal model, authors of this article propose application of multi-criteria decision-making model based on Analytic Hierarchy Process (AHP) method. Input data in the model are based on information from financial statements while MS Excel is used for calculation of such multi-criteria problem. Results of internal model are mathematically related with PD values for each analyzed company.

* H. Volarević, Ph. D., Zagreb School of Economics and Management (E-mail: hrvoje. volarevic@zsem.hr).

** M. Varović, Ph. D., Zagreb School of Economics and Management (E-mail: mario.varovic@zsem.hr). 2018.

The paper was received on February 27th, 2018. It was received for publication on May 11th, 
Simple implementation of this internal model is an advantage compared to other much more complicated models.

Key words: IFRS 9, Expected Credit Losses (ECL), Exposure at Default (EAD), Loss Given Default (LGD), Probability of Default (PD), Analytic Hierarchy Process (AHP), internal model.

\section{Introduction to the problem}

The main purpose of this article is to introduce a new internal model for Expected Credit Losses calculation according to International Financial Reporting Standard 9 (IFRS 9). IASB ${ }^{1}$ initially issued IFRS 9 "Financial instruments" in November 2009 in its project to replace IAS2 39 "Financial Instruments: Recognition and Measurement". After a few updates, finally on 24 July 2014 IASB issued the complete version of IFRS 9 including additional amendments to a new expected loss impairment model. The standard applies to reporting periods beginning on or after 1 January 2018. Since the standard was endorsed by $\mathrm{EFRAG}^{3}$ in November 2016 this means that EU countries, including Croatia, have the same mandatory effective date of initial implementation of IFRS 9 (1 January 2018), with early adoption permitted (Commission Regulation EU 2016/2067 of 22 November 2016).

IFRS 9 was issued in 2014 as a complete standard, including the requirements previously issued and the additional amendments to introduce a new expected loss impairment model and limited changes to the classification and measurement requirements for financial assets. All the business entities that apply IFRS, already in their annual reports for the year 2017, need to present the estimated financial effect for the transition at 1 January 2018. This estimation is impossible without having implemented the new impairment model - Expected Credit Losses (ECL) calculation model.

IFRS 9 is especially relevant for financial institutions but also for business entities that have significant financial assets and liabilities in their Balance sheet. This article is dealing with companies from the Croatian business sector that are classified as big entrepreneurs according to the Croatian Law on Accounting. It must be noted that the implementation of IFRS 9 is not the sole responsibility of the accounting department. Instead, collaboration is needed across several depart-

\footnotetext{
1 International Accounting Standards Board

2 International Accounting Standard

3 European Financial Reporting Advisory Group
} 
ments, including Risk management department, Macroeconomic department (for those that have such experts), Treasury and IT department. They all need to be involved in developing of internal IFRS 9 model and defining methodology for estimating credit risk and calculating the impairment. This methodology needs to be finalized in the form of a standalone document/decision made by the top management (the Board), after being agreed with external auditors. Unlike most published articles on IFRS 9 that are dealing only with the theoretical aspect, this article also deals with the practical research and issues of implementation of IFRS 9, primarily developing an internal model for calculating Expected Credit Losses (ECL model). Thus, it aims at providing expert guidance on how to adopt and what one needs to consider to effectively implement the ECL impairment model.

For the purpose of developing a new ECL internal model authors suggest use of multi-criteria decision making model which is based on Analytic Hierarchy Process (AHP) method. Thomas L. Saaty has introduced and developed in 1980 the AHP method in his book "The Analytic Hierarchy Process: Planning, Priority Setting, Resource Allocation”. Also, he analyzed AHP method in detail in 1990 in an article "How to make a decision: The Analytic Hierarchy Process" and finally in 2008 in another article "Decision making with The Analytic Hierarchy Process”. AHP is a technique for organizing and analyzing complex decisions based on mathematics and psychology. The main objective of implemented internal model will be creation of descending ranking of the selected companies according to the obtained score what is a prerequisite for Probability of Default (PD) calculation.

In the literature review regarding the article's research problem, besides the original text of IFRS 9 "Financial instruments", it is very difficult to find scientific articles dealing specifically with internal model for Expected Credit Loss calculation according to IFRS 9. That is why this article is based mostly on the regulations and guidelines of EU decision making bodies and regulators (Bank for International Settlement, European Banking Authority) as well as official papers from the world's biggest auditing and consulting companies (PricewaterhouseCoopers, KPMG, Ernst \& Young, Grand Thornton). Similar to this topic, in Economic review from September 2011 (Vol. 62, No. 07-08), authors Miodrag Streitenberger and Danijela Miloš Sprčić in their article "Prediktivna sposobnost financijskih pokazatelja u predviđanju kašnjenja u otplati kredita" have examined the use of chosen financial ratios on a sample of small businesses in Croatia in order to identify a company that could default on its payments, using discriminatory analysis. 


\section{Initial research of IFRS 9}

The new standard introduces changes in classification and measurement of financial instruments, and a new impairment model, with extensive new disclosures. It also introduces some changes in the hedge accounting, which are not in scope of this article. The standard requires a new approach for all the financial assets based on the criteria of business model and the contractual cash flow characteristics.

The application of IFRS 9 is retrospective, according to IAS 8 "Accounting Policies, Changes in Accounting Estimates and Errors". The new requirements need to be applied to transactions and business events as if those requirements had always been in effect. The exception are comparative figures that do not need to be restated. IFRS 9 has specific requirements based on impracticability related to the assessment at the date of initial application. One should use reasonable and supportable information that is available without undue cost or effort to determine the credit risk at the date of initial recognition of a financial instrument.

The date of initial application (DIA) is the first date of the reporting period. For most business entities that had not selected the early adoption option, it is 1 January 2018. This means that changes brought by IFRS 9 will be presented for the first time in the annual report for the year 2018 (31 December 2018). But, for those entities that apply IAS 34 "Interim Financial Reporting", the reporting obligation is much sooner, because the DIA transition needs to be presented in the interim, usually semi-annual financial statements as at 30 June 2018.

The DIA transition process includes identifying the assets and liabilities to which IFRS 9 needs to be applied and then assessing the business model and executing the SPPI test. In retrospect, computations for the measurement of financial assets and for the ECL calculations need to be assessed from the date of the initial recognition of financial assets on Balance sheet (e.g. from the date of acquisition of security).

The first criteria, the business model assessment of the DIA transition, must be based on how an entity manages its financial assets and how it generates cash flows, observing through activities undertaken to achieve its business objectives and taking into account the level of risk faced. The IFRS 9 has three business models: "held to collect", "collect and sell" and "for selling" as residual category (Commission Regulation EU 2016/2067 of 22 November 2016).

The second criteria is called "SPPI ${ }^{4}$ test" because an entity should made a distinction between simple-debt "bullet" financial instruments the contractual terms

4 Solely Payment of Principal and Interest 
of which entail only cash flows that are solely payments of principal and related interest, and all the rest. Interest that passes SPPI test should be the compensation for the time value of money, credit risk and cost plus profit margin, consistent with the basic lending arrangement.

According to those two criteria, an entity should classify its financial instrument in one of three categories (IAS 39 used to have four categories) which include "at amortized cost" (AC), "at fair value through other comprehensive income" (FVOCI) and "at fair value through profit and loss" (FVTPL). For the financial instruments that pass the SPPI test, depending on the business model, the top management can choose either one of the three categories. However, in case that the SPPI test fails, the only category left is FVTPL (Commission Regulation EU 2016/2067 of 22 November 2016).

\section{Implementation of the IFRS 9 impairment model}

Credit risk is usually explained as the risk that a borrower may not repay a loan (or any type of debt) so the lender may lose the principal of the loan or the interest on the loan, or both. Credit risk is also called "a default risk" because it implies the Probability of Default. IFRS 9 has single impairment model for all the financial assets, but only for those classified as AC or FVOCI. Financial assets classified as FVTPL do not need to be impaired in this way because they are already "marked to market" with financial effect presented in the P\&L (KPMG, 2016).

The new impairment model is forward looking which is a big change compared to the old IAS 39 incurred loss model that recognized only losses that had arisen from past events, and was criticized for resulting in too little and too late loss provisions. Value adjustments under IAS 39 could only be triggered by the objective facts. The new IFRS 9 impairment model is oriented more towards possible losses in future and therefore an entity should consider much more information in determination of such expectations of future credit losses. It involves anticipatory Expected Credit Losses model that is expected to lead to the creation of much bigger risk provisions without fulfilling the objective impairment triggers of IAS 39. The new impairment model should be activated on the booking date 1 January 2018 in the transition process for the financial assets AT and FVOCI. Credit risk at DIA should be compared with the credit risk of initial recognition in past, so changes in credit quality can be identified (EY, 2014).

The new ECL impairment model consists of three stages for impairment based on changes in credit quality (credit deterioration), that are shown in Figure 1. 
Figure 1:

THREE STAGES FOR IMPAIRMENT ACCORDING TO ECL MODEL

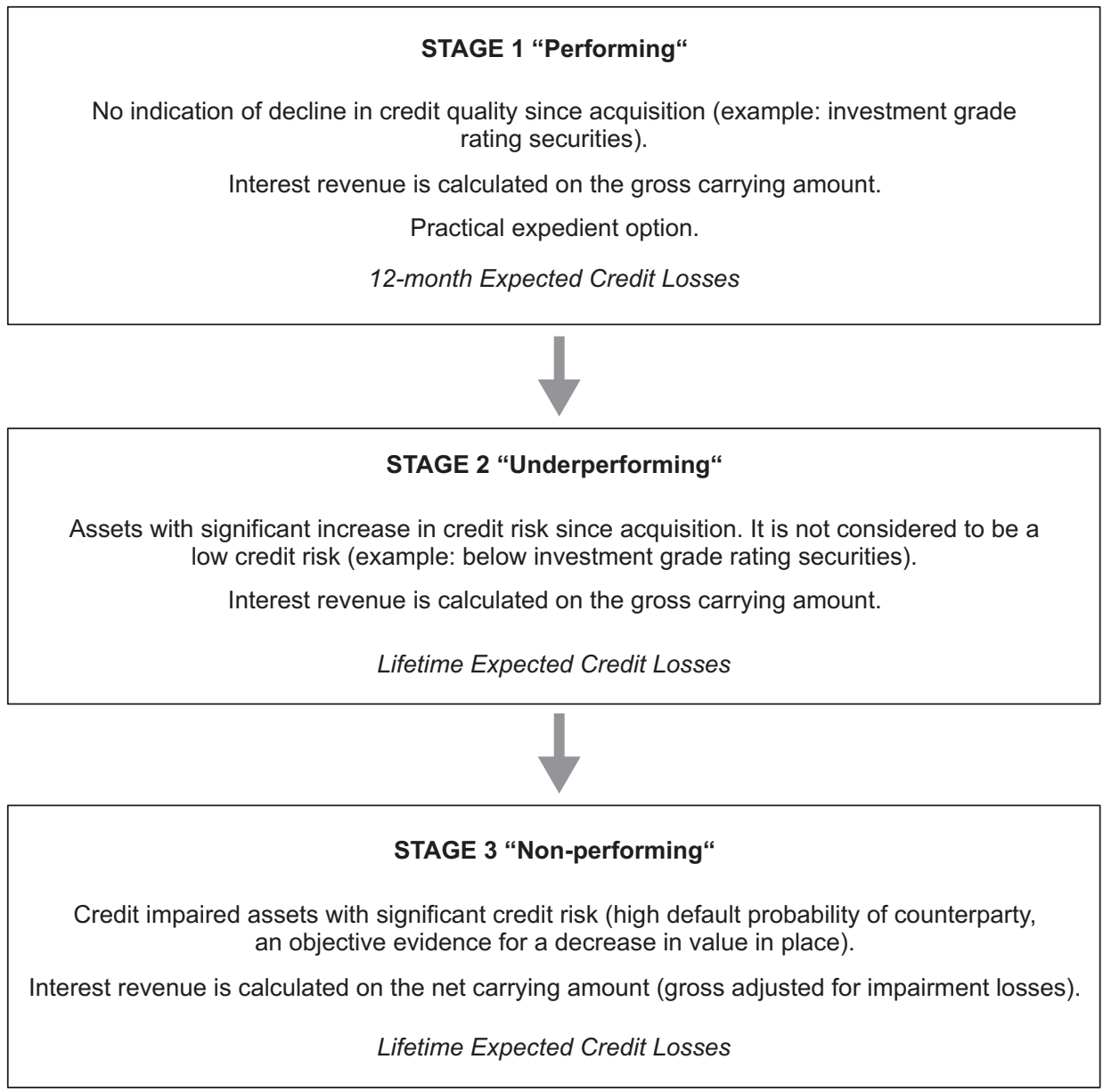

Source: Created by the authors according to the IFRS 9 - Financial Instruments.

Recognition of Expected Credit Losses in Balance sheet (impairment/loss provisions) and in Income statement (expenses) can be either 12-month of lifetime for each financial asset, depending on the impairment stage the asset falls in. Exemplary indicator for reallocating the financial asset from stage 1 to stage 2 is a significant change in the external credit rating (e.g. from AA to BB), significant deterioration of the company results (profit, turnover, sales), significant value de- 
cline of collaterals received and days overdue for payments (usually, a 30-day delay implies automatic allocation to stage 2, unless proven differently) (EBA, 2017).

\section{Figure 2:}

\section{EXAMPLE OF ENTRIES IN THE BUSINESS BOOKS FOR CALCULATED 12-MONTHS ECL ON DIA AND ON REPORTING DATE}

\begin{tabular}{|c|c|c|}
\hline \multicolumn{3}{|l|}{ a) For financial asset classified as AT (given loan) } \\
\hline On the date of initial application (DIA; 1 January 2018): & & \\
\hline Debit retained earnings (capital \& reserves in BS) & $\mathrm{xx}$ & \\
\hline Credit loan impairment / value adjustment (Assets in BS) & & $x \mathrm{x}$ \\
\hline On the Balance sheet date (31 December 2018): & & \\
\hline Debit impairment expenses (P\&L) & $x \mathrm{x}$ & \\
\hline Credit loan impairment / value adjustment (Assets in BS) & & $x \mathrm{x}$ \\
\hline b) For a financial asset classified as $\mathrm{FVOCI}$ (purchased security) & & \\
\hline On the date of initial application (DIA; 1 January 2018): & & \\
\hline Debit retained earnings (capital \& reserves in BS) & $x x$ & \\
\hline Credit impairment provisions (capital \& reserves in BS) & & $x \mathrm{x}$ \\
\hline On the Balance sheet date (31 December 2018): & & \\
\hline Debit impairment expenses (P\&L) & $\mathrm{xx}$ & \\
\hline Credit impairment provisions (capital \& reserves in BS) & & $x x$ \\
\hline
\end{tabular}

Source: Created by the authors.

Example of booking entries in Figure 2 shows different approach in ECL recognition in Balance sheet for AT and for FVOCI. Given loan classified as "at amortized cost" (AT) has its accompanying account ("loan impairment" or "value adjustment") that is presented in Balance sheet next to the principle account for given loan, both as Assets. On the other hand, purchased security classified as "at fair value through other comprehensive income" (FVOCI) does not have an impairment account on the asset side, but instead uses impairment provision account in capital \& reserves. The reason is because financial assets classified as FVOCI must be presented on the asset side of Balance sheet at their fair value (usually quoted market price on the stock exchange), so fair value cannot be directly impaired (EY, 2014). 
One important issue to be noticed from bookings in Figure 2 is different debit account to be used depending on the Balance sheet date. If you book ECL on date of initial recognition, which for most entities is 1 January 2018, then the financial effect of calculated credit losses goes to capital \& reserves in Balance sheet and charges retained earnings. This is one-time exemption for the transition from IAS 39 to IFRS 9. For all the rest reporting dates including for semi-annual report (30 June 2018) and annual report for 2018 (31 December 2018), you cannot debit retained earnings, but you should always use the expense account in P\&L. Thus, the financial effects of regular ECL calculations after 1 January 2018 will decrease the financial result for the current year, thus playing a very important role in financial reporting and initiating interesting discussions with your external auditors (Grant Thornton, 2016).

The new ECL model is expected to be very complex, but IFRS 9 provides a shortcut simplification for low credit risk financial assets in form of a practical expedient option. Low credit risk can be justified with high investment grade given by the external rating agencies. Holy trinity is of course represented by the Big Three credit rating agencies: Standard \& Poor's (S\&P), Moody's and Fitch.

The consequences of introducing IFRS 9 to your accounting would very likely be a significant increase in value adjustments and/or (risk) impairment provisions that will in the short run, especially for the first year after transition, burden the retained earnings and income statement, causing less profit and less distributable income. But, for the following years, under the assumption that the entity would carefully manage its credit risk, a new balance will be created. The old financial assets that will be due, matured or sold will be derecognized in the business books and the aliquot part of the value adjustment previously recognized, would be transferred to income side of $\mathrm{P} \& \mathrm{~L}$, facing new impairment expenses that will arise from the acquisition of the new financial instruments and their ECL calculations. The standard allows the credit risk assessment of financial assets on a portfolio level (group / category) but it has to consist of financial instruments with common credit risk characteristics (like instrument type, credit risk ratings, maturity date, collateral, geographical regions) (BIS, 2015).

The biggest problem in practical implementation of the new impairment model is the fact that IFRS 9 does not prescribe a specific measurement method for calculating ECL model. Quite the opposite, entities are expected to develop their internal models using reasonable and supportable information from the past and from the future. Accountants are well aware that such a freedom looks nice only from the outside, but when it comes to real life, a thousand questions appear, and you have no one to ask. Actually, you can ask for help, but it is not free of charge, far from it. It can cost you a fortune to fully implement IFRS 9 if you cannot make it on your own. 


\section{ECL MODEL AS A MAIN OBJECTIVE}

ECL calculation model should calculate an unbiased and probability weighted amount to be presented as impairment to book value of financial asset in Balance sheet and it will be represent in this article as the main objective. Management can adopt one of several methods in computing ECL. If an entity already has in place an internal risk management model, maybe it can be updated and used for the purpose of IFRS 9. But, most entities would have to start from scratch and probably will find as very acceptable and convenient the following explicit Probability of Default approach, shown in Figure 3.

Figure 3:

\section{FORMULA FOR ECL CALCULATION}

$$
\mathrm{ECL}=\mathrm{EAD} \times \mathrm{LGD} \times \mathrm{PD}
$$

Source: KPMG (2017). Demystifying Expected Credit Loss (ECL).

Speaking mathematically, Expected Credit Losses that need to be computed and presented as value adjustments are the product of three variables. The first variable is Exposure at Default (EAD), the second variable is Loss Given Default (LGD) and the third, and the most sensitive variable to determine is Probability of Default (PD) (KPMG, 2017).

Variable EAD is the amount of money that is invested in certain financial instrument that is exposed to credit risk. Basel legislation define EAD as the gross exposure under a facility upon default of an obligor, which is a parameter used in the calculation of bank's capital. Outside Basel, it is known as "credit exposure" which represents a loss that a lender would suffer if the borrower (counterparty) fully defaults on his debt (e.g. cannot repay the loan received). In practice, ECL calculation uses bookkeeping balance of the account for certain financial instrument as at reporting date of Balance sheet for which we calculate ECL (e.g. for calculating annual ECL for 2018 for the given loan we shall use the balance of account "loans given" in Assets in Balance sheet as at 31 December 2018).

Variable LGD is the share of a financial asset that we shall lose if a borrower defaults. This parameter is also often used in the calculations under Basel legislation. On the other hand, the recovery rate $(\mathrm{RR})$ is calculated as " $1-\mathrm{LGD}$ ". So, the 
recovery rate is the remaining share of a financial asset that we expect to recover when a borrower defaults. For example, if we give credit of $1.000 \mathrm{HRK}$, and our debtor starts to experience some difficulties, we will calculate what part of credit we can expect debtor will repay $(\mathrm{RR}=55 \%, 1,000 \times 55 \%=550 \mathrm{HRK})$, and what part of credit we will lose $(\mathrm{LGD}=1-\mathrm{RR}=1-0.55=0.45 \times 100=45 \% ; 1,000$ $\times 45 \%=450 \mathrm{HRK})$. We must make a distinction, when calculating the value of variable LGD, whether we have exposure with or without collateral. In previous example, the value of LGD on our given loan is $45 \%$ (which corresponds to Basel's recommendation) because there is no collateral as a means of insurance and the credit risk is bigger. Alternatively, if we receive a security as a collateral for the given loan, then we will calculate the effective Loss Given Default that will be less than $45 \%$ (so, in other words we expect bigger rate of return than previously $55 \%$ because we can use collateral in case of default) (PWC, 2017).

Variable PD stands for likelihood of a default of a counterparty over an observed period, usually 12 months, so an estimate of probability that a debtor will not be able to meet its debt obligations in time or in full. PD is a key parameter under Basel. PD calculation includes analyses of debtor's cash flow adequacy in servicing debt, operating margin, percentage of leverage used, and declining liquidity. There are many ways to estimate PD. It can be done by analyzing the historical data base of actual defaults that really happened to your company or by observing the prices of credit default swaps (CDS), bonds and options on common shares. But, the most practical way is to directly use external ratings from S\&P, Fitch and Moody's that are based on historical data across the financial market. Those external ratings imply a certain level of default probability and are (or should be) objective and neutral.

For calculating ECL two types of PDs are used. For stage 1, in case of a low credit risk, we use 12-month PD as the estimated Probability of Default occurring within next 12 month (one year) or over the remaining maturity of the financial instrument (e.g. receivables) that is less than 12 months. For stage 2 and 3, in case of significant increase of credit risk, we need to calculate lifetime PD as the estimated Probability of Default occurring over the remaining life of the financial instrument, which is over 1 year (PWC, 2015).

Basel legislation favor the use of through-the-cycle (TTC) for probabilities of default (PD), but also for LGD and EAD. Contrary to that, IFRS 9 calls for the use of the point-in-time (PIT) estimation of PD, LGD and EAD. PIT ratings evaluate the current situation of the counterparty by taking into account both permanent and cyclical effect, while TTC ratings focus mostly on the permanent component of default risk. In this article, for the purpose of developing simplified and practical internal ECL model, we did not make a distinction between those two philosophical standpoints (Topp, Perl, 2010). 
IFRS 9 requires the ECL calculation for all the financial instruments in Balance sheet that are exposed to credit risk. This article will focus on the financial assets on the asset side of Balance sheet. Financial assets usually include: current accounts (a vista), term deposits placed, loans given, reverse repo deposits, debt securities purchased, trade receivables. Cash money in our cashier's desk is not exposed to credit risk because it is money is in our hands; there is no counterparty, so there is no need to calculate ECL for cash.

This is a small practical research for calculating ECL using the above formula from Figure 3. Assuming we have a loan of 1,000,000 HRK given to counterparty XY (credit debtor) with accrued interest on the reporting date of 5,000 HRK. Our internal risk model gives us the value of 12-month PD for counterparty $\mathrm{XY}$ of $7 \%$. Since there is no collateral received for the given loan, we can use the standard value for LGD that is recommended by Basel legislation (45\%).

$$
\begin{aligned}
12 \text {-month } \mathrm{ECL} & =\mathrm{EAD} \times \mathrm{LGD} \times \mathrm{PD} \\
& =(1,000,000+5,000) \times 45 \% \times 7 \% \\
& =1,005,000 \times 0.45 \times 0.07 \\
& =31,657.50 \mathrm{HRK}
\end{aligned}
$$

So, based on this ECL calculation, in our business books we shall debit the impairment expense in P\&L for the amount 31,657.50 HRK, and credit the value adjustment for the loan given in Balance sheet.

\subsection{Definition of EAD - Exposure at Default}

Exposure at Default in the ECL calculation comes from the Accounting department, it is a bookkeeping amount of certain financial instrument from Balance sheet for which we would like to calculate Expected Credit Losses. We will need EAD for the initial ECL calculation on the recognition date, when the financial instrument was acquired, for the first time. After that, we will need a bookkeeping balance for the each reporting date for which we need to do the ECL calculation. The amount of EAD is not just the principal of the given loan, or just the nominal value of the security bought. EAD amount depends on the type of financial instrument. Below is the definition of EAD amounts for the most common types of financial instruments that can usually be found in Assets on the Balance sheet of business entities, on reporting date:

Loans given - EAD consists of the principle plus accrued interest up to the reporting date. 
Deposits placed - EAD consists of the principle plus accrued interest up to the reporting date.

$>$ Reverse repo operations - in its accounting essence it is a deposit placed so EAD comprises principle plus accrued interest up to the reporting date.

$>$ Debt securities purchased with discount (discounted securities) - EAD is an amortized value plus accrued interest up to the reporting date. Amortized value of a discounted security is its nominal value minus the remaining (unamortized) portion of the discount.

$>$ Debt securities purchased with premium - EAD is an amortized value plus accrued interest up to the reporting date. Amortized value is its nominal value plus unamortized portion of premium.

$>$ Trade receivables - EAD amount is the nominal value of our receivables from counterparties (customers). IFRS 9 offers possible simplification for ECL calculation of trade receivables (PWC, 2015).

There is no difference in calculating EAD amount for debt securities classified in portfolio "at amortized cost" (AT) in relation to debt securities in portfolio "at fair value through other comprehensive income" (FVOCI). Although securities in FVOCI are presented in Balance sheet at fair value, when calculating EAD amount, we will not take into account the revaluation account (adjustment with market value), but only the amortized value.

\subsection{Calculation of LGD - Loss Given Default}

Many business entities that need to apply IFRS 9 are also subject to Basel legislation, which relates especially to financial institutions, primarily banks. Therefore, supervisory requirements interact with Expected Credit Losses measurement. Since IFRS 9 does not prescribe detailed methods of techniques for calculating Expected Credit Losses, it is not forbidden to "lend" part of the elaborated modelling approach clearly defined in Capital Requirements Regulation - CRR (Regulation EU No 575/2013 on prudential requirements for credit institutions and investment firms). Basel legislation (CRR) on LGD modelling and calculation provide some ready answers, already tested in risk management in practice. In Article 161 (CRR) it is prescribed that institutions shall use fixed LGD value $45 \%$ (coefficient 0.45) for non-collateralized financial instruments (for senior exposures without eligible collateral). This fixed percentage is a result of historic statistical analysis of the share the creditors in average lost when borrowers defaulted. It means that in case of counterparty's default, we will lose 45 out of 100 invested (Regulation EU No 575/2013). 
Exposure with collateral received is much less risky. Simple calculation: counterparty defaults with an outstanding debt of 1,000 but we can sell a security that we received as a collateral for 850 , so we lose the difference $(1,000-850=$ $150)$ and LGD is $15 \%(15 / 1,000=0.15 \times 100=15 \%)$.

In Article 223 there is a formula for calculation of the volatility-adjusted value of the security received as the collateral using comprehensive method (Figure 4) (Regulation EU No 575/2013).

Figure 4:

FINANCIAL COLLATERAL COMPREHENSIVE METHOD

\begin{tabular}{|l|}
\hline $\mathrm{C}_{\mathrm{VA}}=\mathrm{C} \times\left(1-\mathrm{H}_{\mathrm{C}}-\mathrm{H}_{\mathrm{FX}}\right)$ \\
\hline $\mathrm{C}_{\mathrm{VA}}=$ the volatility-adjusted value of the collateral \\
$\mathrm{C}=$ the value of the collateral (market value of the security received) \\
$\mathrm{H}_{\mathrm{C}}=$ corrective factor ("haircut") for market value volatility adjustment \\
$\mathrm{H}_{\mathrm{FX}}=$ corrective factor ("haircut") for currency mismatch
\end{tabular}

Source: Regulation (EU) No 575/2013 of the European Parliament and of the Council of 26 June 2013 on prudential requirements for credit institutions and investment firms and amending Regulation (EU) No 648/2012, Official Journal of the European Union 27.06.2013.

Business entities need to take into account two types of corrective factors often referred to as "haircuts". The first haircut $\left(\mathrm{H}_{\mathrm{C}}\right)$ corrects the value of collateral for market value volatility using the data from Article 224 of CRR shown in Table 1. The selected coefficient from the Table 1 should reflect the right credit quality $(1-4)$, the residual maturity $(1-5$ years $)$ and the time in which you can sell the collateral (5 / 10 / 20 days) (Regulation EU No 575/2013). 
Table 1:

\section{VOLATILITY ADJUSTMENTS - MARKET VALUE VOLATILITY ADJUSTMENT}

\begin{tabular}{|c|c|c|c|c|c|c|c|c|c|c|}
\hline \multirow[t]{2}{*}{$\begin{array}{l}\text { Credit quality } \\
\text { step with which } \\
\text { the credit } \\
\text { assessment of } \\
\text { the debt security } \\
\text { is associated }\end{array}$} & \multirow[t]{2}{*}{$\begin{array}{l}\text { Residual } \\
\text { Maturity }\end{array}$} & \multicolumn{3}{|c|}{$\begin{array}{l}\text { Volatility adjustments for debt securities } \\
\text { issued by entities described in } \\
\text { Article } 197(1) \text { (b) }\end{array}$} & \multicolumn{3}{|c|}{$\begin{array}{l}\text { Volatlity adjustments for debt securities } \\
\text { issued by entities described in } \\
\text { Article } 197(1) \text { (c) and (d) }\end{array}$} & \multicolumn{3}{|c|}{$\begin{array}{l}\text { Volatility adjustments for securitisation } \\
\text { positions and meeting the criteria in } \\
\text { Article } 197 \text { (1) (h) }\end{array}$} \\
\hline & & $\begin{array}{l}\text { 20-day } \\
\text { liquidation } \\
\text { period (96) }\end{array}$ & $\begin{array}{l}\text { 10-day } \\
\text { liquidation } \\
\text { period (\%) }\end{array}$ & $\begin{array}{l}\text { 5-day } \\
\text { liquidation } \\
\text { period (96) }\end{array}$ & $\begin{array}{l}\text { 20-day } \\
\text { liquidation } \\
\text { period }(\%)\end{array}$ & $\begin{array}{l}\text { 10-day } \\
\text { liquidation } \\
\text { period ( } 8 \text { ) }\end{array}$ & $\begin{array}{l}\text { 5-day } \\
\text { liquidation } \\
\text { period (\%) }\end{array}$ & $\begin{array}{l}\text { 20-day } \\
\text { liquidation } \\
\text { period (\%) }\end{array}$ & $\begin{array}{l}\text { 10-day } \\
\text { liquidation } \\
\text { period (\%) }\end{array}$ & $\begin{array}{l}\text { 5-day } \\
\text { liquidation } \\
\text { period (S) }\end{array}$ \\
\hline \multirow[t]{3}{*}{1} & $\leq 1$ year & 0,707 & 0,5 & 0,354 & 1,414 & 1 & 0,707 & 2.829 & 2 & 1,414 \\
\hline & $>1 \leq 5$ years & 2.828 & 2 & 1,414 & 5,657 & 4 & 2,828 & 11,314 & 8 & 5.657 \\
\hline & $>5$ years & 5,657 & 4 & 2.828 & 11,314 & 8 & 5,657 & 22,628 & 16 & 11,313 \\
\hline \multirow[t]{3}{*}{$2-3$} & $\leq 1$ year & 1.414 & 1 & 0.707 & 2.828 & 2 & 1,414 & 5.657 & 4 & 2.828 \\
\hline & $>1 \leq 5$ years & 4,243 & 3 & 2,121 & 8.485 & 6 & 4,243 & 16.971 & 12 & 8,485 \\
\hline & $>5$ years & 8.485 & 6 & 4,243 & 16.971 & 12 & 8.485 & 33,942 & 24 & 16.970 \\
\hline \multirow[t]{3}{*}{4} & $\leq 1$ year & 21,213 & 15 & 10,607 & $N / A$ & $\mathrm{~N} / \mathrm{A}$ & $N / A$ & $N / A$ & $N / A$ & $\mathrm{~N} / \mathrm{A}$ \\
\hline & $>1 \leq 5$ years & 21.213 & 15 & 10,607 & $N / A$ & $\mathrm{~N} / \mathrm{A}$ & $N / A$ & $N / A$ & $\mathrm{~N} / \mathrm{A}$ & $N / A$ \\
\hline & $>5$ years & 21,213 & 15 & 10,607 & $N / A$ & $\mathrm{~N} / \mathrm{A}$ & $\mathrm{N} / \mathrm{A}$ & $\mathrm{N} / \mathrm{A}$ & $\mathrm{N} / \mathrm{A}$ & $\mathrm{N} / \mathrm{A}$ \\
\hline
\end{tabular}

Source: Regulation (EU) No 575/2013 of the European Parliament and of the Council of 26 June 2013 on prudential requirements for credit institutions and investment firms and amending Regulation (EU) No 648/2012, Official Journal of the European Union 27.06.2013.

The second haircut $\left(\mathrm{H}_{\mathrm{FX}}\right)$ should be used in case when the currency of the collateral is not the same as the currency of the underlying financial instrument. Table 2 (from Article 224 of CRR) shows predefined coefficient values, also taking into account the liquidation period of the security received. For example, if we give a loan of 10.000 USD and we receive as collateral a debt security denominated in EUR, there is a currency mismatch. If in the case of default, there is an active market for this type of security, we can presumably sell it in 10 days, so the haircut coefficient would be $8 \%$ (Regulation EU No 575/2013). 
Table 2:

VOLATILITY ADJUSTMENTS - CURRENCY MISMATCH

\begin{tabular}{c|c|c}
\hline $\begin{array}{c}\text { 20-day liquidation period } \\
(\%)\end{array}$ & $\begin{array}{c}\text { 10-day liquidation period } \\
(\%)\end{array}$ & $\begin{array}{c}\text { 5-day liquidation period } \\
\%)\end{array}$ \\
\hline 11,314 & 8 & 5,657 \\
\hline
\end{tabular}

Source: Regulation (EU) No 575/2013 of the European Parliament and of the Council of 26 June 2013 on prudential requirements for credit institutions and investment firms and amending Regulation (EU) No 648/2012, Official Journal of the European Union 27.06.2013.

The next step, shown in Figure 5, is the calculation of the volatility-adjusted value of the exposure $\left(\mathrm{E}_{\mathrm{VA}}\right)$ (Regulation EU No 575/2013).

Figure 5:

\section{CALCULATION OF E $\mathrm{VA}_{\mathrm{V}}$}

\begin{tabular}{|l|}
\hline $\mathrm{E}_{\mathrm{VA}}=\mathrm{E} \times\left(1+\mathrm{H}_{\mathrm{E}}\right)$ \\
\hline $\mathrm{E}_{\mathrm{VA}}=$ the volatility-adjusted value of the exposure \\
$\mathrm{E}=$ the exposure value of the underlying financial instrument without a collateral \\
$\mathrm{H}_{\mathrm{E}}=$ corrective factor for the exposure
\end{tabular}

Source: Regulation (EU) No 575/2013 of the European Parliament and of the Council of 26 June 2013 on prudential requirements for credit institutions and investment firms and amending Regulation (EU) No 648/2012, Official Journal of the European Union 27.06.2013.

The volatility-adjusted value of the loan $\left(\mathrm{E}_{\mathrm{vA}}\right)$ is calculated using the amount of loan (E i.e. EAD) and haircut for term exposure $\left(\mathrm{H}_{\mathrm{E}}\right)$.

Business entities shall then calculate the Adjusted value of the exposure $\left(\mathrm{E}^{*}\right)$ that takes into account the previous steps, the volatility-adjusted value of the exposure $\left(\mathrm{E}_{\mathrm{VA}}\right)$ and the volatility-adjusted value of the collateral $\left(\mathrm{C}_{\mathrm{VA}}\right)$ :

$$
\mathrm{E}^{*}=\max \left\{0, \mathrm{E}_{\mathrm{VA}}-\mathrm{C}_{\mathrm{VA}}\right\}
$$


Adjusted value of the exposure ( $\left.\mathrm{E}^{*}\right)$ for a loan will be zero if the volatilityadjusted value of the security received as a collateral $\left(\mathrm{C}_{\mathrm{VA}}\right)$ is bigger than the volatility-adjusted value of the exposure for a loan $\left(\mathrm{E}_{\mathrm{VA}}\right)$. There would be no exposure left (Regulation EU No 575/2013). Finally, entities should calculate the effective LGD (LGD*) according to the Article 228:

$$
\mathrm{LGD}^{*}=\mathrm{LGD} \times \mathrm{E}^{*} / \mathrm{E}
$$

Effective LGD (LGD*) for a loan is the multiplication of non-collateralized LGD (45\%) with uncovered (the part that remained exposed) part of a loan ( $\left.\mathrm{E}^{*}\right)$ in regards to the total value of a loan (total exposure). This percentage of effective LGD* is further used in ECL calculation.

Practical research for LGD calculation: Our company has given a loan of 1,000,000 HRK and we received a German government debt security denominated in EUR with market value of 1,030,000 HRK (kuna equivalent). The maturity of the loan is the same as the maturity of the security (2 years). There is a quite active market for this type of security and it can be sold in 6-8 days.

$$
\begin{aligned}
& \mathrm{E}(\mathrm{EAD})=1,000,000 \mathrm{HRK} \\
& \mathrm{C}=1,030,000 \mathrm{HRK}(\mathrm{HRK} \text { equivalent }) \\
& \mathrm{H}_{\mathrm{C}}=15 \% \\
& \mathrm{H}_{\mathrm{FX}}=8 \% \\
& \underline{\mathrm{H}}_{\underline{\mathrm{E}}}=0 \% \\
& \begin{aligned}
\mathrm{LGD}^{*} & =? \\
\mathrm{C}_{\mathrm{VA}} & =\mathrm{C} \times\left(1-\mathrm{H}_{\mathrm{C}}-\mathrm{H}_{\mathrm{FX}}\right) \\
& =1,030,000 \times(1-0.15-0.08) \\
& =1,030,000 \times 0.77=793,100 \mathrm{HRK} \\
& =\mathrm{E} \times\left(1+\mathrm{H}_{\mathrm{E}}\right) \\
& =1,000,000 \times(1+0)=1,000,000 \mathrm{HRK} \\
\mathrm{E}_{\mathrm{VA}} & \max \left\{0, \mathrm{E}_{\mathrm{VA}}-\mathrm{C}_{\mathrm{VA}}\right\} \\
\mathrm{E}^{*} & \max \{0,1,000,000-793,100\} \\
& =\max \{0,206,900\}=206,900 \mathrm{HRK} \\
\mathrm{LGD}^{*} & =\mathrm{LGD} \times \mathrm{E}^{*} / \mathrm{E} \\
& =45 \% \times 206,900 / 1,000,000 \\
& =45 \% \times 0.2069=9.31 \%
\end{aligned}
\end{aligned}
$$




\subsection{Calculation of PD - Probability of Default}

For the purpose of ECL calculation we need to determine the value of Probability of Default (PD). Depending on the type of the underlying financial instrument we have to distinguish the PD of the counterparty - the debtor (to whom you gave the loan) and PD of the issuer of the purchased debt security.

There are two ways to determine PD. The easiest way is to look it up in transition matrices for time horizon of one year, published by external rating agencies. Basic assumption is that your counterparty / issuer is a big company that is included in the external ratings process. This is usually the case for issuers of debt securities quoted on big stock exchanges around the world. Big external rating agencies, for example Standard \& Poor's, publish several types of transition matrices (TM), the most interesting for ECL calculations are TM for sovereign issuers, supranational issuers, financial institutions and for corporate issuers (Standard \& Poor's, 2017).

Table 3:

STANDARD \& POOR'S TRANSITION MATRIX (TM) FROM 2016

\begin{tabular}{|c|c|c|c|c|c|c|c|c|c|}
\hline From/to & AAA & AA & A & BBB & BB & B & $\mathrm{ccc} / \mathrm{C}$ & D & NR \\
\hline \multicolumn{10}{|l|}{ One-year } \\
\hline \multirow[t]{2}{*}{ AAA } & 87.05 & 9.03 & 0.53 & 0.05 & 0.08 & 0.03 & 0.05 & 0.00 & 3.17 \\
\hline & $(7.14)$ & $(7.16)$ & $(0.83)$ & $(0.25)$ & $(0.25)$ & $(0.17)$ & $(0.35)$ & $(0.00)$ & $(2.42)$ \\
\hline \multirow[t]{2}{*}{$\mathrm{AA}$} & 0.52 & 86.82 & 8.00 & 0.51 & 0.05 & 0.07 & 0.02 & 0.02 & 3.99 \\
\hline & $(0.52)$ & $(5.25)$ & $(4.21)$ & $(0.69)$ & $(0.20)$ & $(0.21)$ & $(0.07)$ & $(0.08)$ & $(1.89)$ \\
\hline \multirow[t]{2}{*}{$\mathrm{A}$} & 0.03 & 1.77 & 87.79 & 5.33 & 0.32 & 0.13 & 0.02 & 0.06 & 4.55 \\
\hline & $(0.09)$ & $(1.02)$ & (3.53) & (2.11) & $(0.39)$ & $(0.27)$ & $(0.07)$ & $(0.11)$ & $(1.77)$ \\
\hline \multirow[t]{2}{*}{ BBB } & 0.01 & 0.10 & 3.51 & 85.56 & 3.79 & 0.51 & 0.12 & 0.18 & 6.23 \\
\hline & $(0.04)$ & $(0.16)$ & (1.65) & $(3.73)$ & (1.52) & $(0.70)$ & $(0.22)$ & $(0.26)$ & (1.59) \\
\hline \multirow[t]{2}{*}{$\mathrm{BB}$} & 0.01 & 0.03 & 0.12 & 4.97 & 76.98 & 6.92 & 0.61 & 0.72 & 9.63 \\
\hline & $(0.06)$ & $(0.09)$ & $(0.26)$ & $(1.89)$ & $(4.41)$ & $(3.12)$ & $(0.76)$ & $(0.85)$ & $(2.38)$ \\
\hline \multirow[t]{2}{*}{ B } & 0.00 & 0.03 & 0.09 & 0.19 & 5.15 & 74.26 & 4.46 & 3.76 & 12.06 \\
\hline & $(0.00)$ & $(0.09)$ & $(0.21)$ & $(0.22)$ & (2.04) & $(4.22)$ & (2.19) & (3.25) & $(2.19)$ \\
\hline \multirow[t]{2}{*}{$\mathrm{CCC} / \mathrm{C}$} & 0.00 & 0.00 & 0.13 & 0.19 & 0.63 & 12.91 & 43.97 & 26.78 & 15.39 \\
\hline & $(0.00)$ & $(0.00)$ & $(0.45)$ & $(0.69)$ & $(0.97)$ & $(8.02)$ & $(9.03)$ & (11.48) & $(5.43)$ \\
\hline
\end{tabular}

Source: https://www.spratings.com/documents/20184/774196/2016+Annual+Global+Corporate+ Default+Study+And+Rating+Transitions.pdf/2ddcf9dd-3b82-4151-9dab-8e3fc70a7035

Table 3 shows $\mathrm{S} \&$ P's transition matrix for corporate issuers for 2016 issued in April 2017, and we can see that for credit rating "BB" default rate is $0.72 \%$. 
If your counterparty has external rating "BB" then this percentage would be the value of PD variable for ECL calculation. Optionally, PD could be adjusted if you proportionately correct the values in column " $\mathrm{D}$ " with the values from column "NR" (not-rated). Additionally, if the PD value is very low i.e. close to zero, then you should define a minimal value for PD in your internal methodology. In Article 163 (CRR) it is prescribed that institutions should use PD of at least $0.03 \%$ (Regulation EU No 575/2013).

The second way, the hard way, is when your counterparty is not rated by external rating agencies, so it has no rating, and no externally available value of PD. IFRS 9 requires that you have to set up an internal model for determining the PD value. In literature you can find several very sophisticated and mathematically demanding techniques to do that. The authors suggest using Analytic Hierarchy Process (AHP) which is a multi-criteria decision making method based on mathematics and psychology. AHP was developed by Thomas L. Saaty in the 1980 and it has been widely used in various fields (business, education, industry etc.). AHP structures a decision problem, quantifies its elements and links with goals, and evaluates alternative solutions which in the end enables ranking of solutions. Its popularity is based primarily on the fact that it is very similar to the way in which an individual would solve complex problems by simplifying them. Psychology shows that the human brain operates simply, that is, at the level of comparing possible pairs. It is difficult to give consistent estimates for several alternatives on multiple criteria (Saaty, 1990).

Another important reason lies in the fact that the use of this method does not require a mathematical background. Finally, the third important reason why this method is so popular is the possibility to use MS Excel for calculation.

In this article we will introduce an internal model for PD and therefore ECL calculation in 9 steps which incorporates six different criteria for five selected Croatian companies. Five companies are selected from the list of ten biggest entrepreneurs in the Croatian business sector according to total revenues in 2016. Only one of them (HEP group) has an external rating from Standard \& Poor's rating agency. The five selected Croatian companies are: (1) INA group, (2) HEP group, (3) HT group, (4) PLIVA Ltd. and (5) PLODINE Plc. Data are obtained from their consolidated financial statements for the year 2016, available on their internet pages and internet page of FINA (public announcement by Financial Agency).

\section{Step 1 - Selection of financial ratios}

Authors have selected the following six financial ratios from the four main groups of financial indicators (Atrill, McLaney, 2006) that will serve as criteria 
(CR): CR 1. Net profit margin - NPM; CR 2. Return on Asset - ROA; CR 3. Debt ratio - DR; CR 4. Interest coverage ratio - ICR; CR 5. Current ratio - CR; CR 6. Receivables turnover - RT. They reflect the level of credit risk very well, and are easy to calculate (this article will not deal with economic explanation of selected indicators). In addition to the selected indicators that are based on the accounting data from the financial statements, i.e. from the past, in the internal model we can also use some other indicators that are more "forward looking", e.g. macroeconomic indicators like the GDP growth rate for the next year and so on.

\section{Step 2 - Calculation of financial indicators}

We will create a decision matrix ( 5 rows $\times 6$ columns) and input calculated values for five selected companies and their six indicators $\left(\mathrm{Y}_{\mathrm{ij}}\right)$. All values are in units of measurement in which they are usually expressed (absolute and percentage values). Objective function for some of the indicators is to maximize their value (benefit criteria) and for other indicators is the opposite - to minimize their value (cost criteria).

Table 4:

\section{DEFINING OF 6 CRITERIA (BENEFIT AND COST CRITERIA)}

\begin{tabular}{|c|c|c|c|c|c|c|c|}
\hline No & COMPANY & CR1 - NET PROFIT MARGIN & CR2 - RETURN ON ASSET & CR3 - DEBT RATIO & CR4- INTEREST COVERAGE RATIO & CRS - CURRENT RATIO & CR6 - RECEIVABLES TURNOVER \\
\hline & & & & & & & \\
\hline & & $0,01 \%$ & $2,95 \%$ & $4,, 18 \%$ & 2,41 & 0,10 & 10,20 \\
\hline 2 & HEP GROUP & $15,76 \%$ & $6,94 \%$ & $35,05 \%$ & 7,45 & 1,65 & 7,49 \\
\hline 3 & HT GROUP & $13,31 \%$ & $8,57 \%$ & $16,66 \%$ & 8,60 & 3,01 & 5,42 \\
\hline 4 & PLIVA Ltd & $17,18 \%$ & $11,22 \%$ & $39,21 \%$ & 4,16 & 1,05 & 2,88 \\
\hline 5 & PLODINEPIC & $2,21 \%$ & $5,38 \%$ & $82,13 \%$ & 1,95 & 0,42 & 53,99 \\
\hline \multicolumn{2}{|c|}{ objective funcion: } & $\max$ & $\max$ & $\min$ & $\max$ & $\max$ & $\max$ \\
\hline \multicolumn{2}{|r|}{ criterion: } & $Y_{1}$ & $Y_{2}$ & $Y_{3}$ & $\mathrm{Y}_{4}$ & $Y_{5}$ & $Y_{6}$ \\
\hline & ERAGE VALUE: & $9,81 \%$ & $7,02 \%$ & $44,17 \%$ & 4,92 & 1,38 & 16,00 \\
\hline
\end{tabular}

Source: Created by the authors. 


\section{Step 3 - Calculation of six benefit criteria}

Next step is to define decision matrix according to the six given criteria ( $\mathrm{Y}$ for $j=1,2,3,4,5$, and 6 ). In this internal model we have 5 benefit criteria (max) and only 1 cost criterion ( $\mathrm{min}$ ), which is the debt ratio (CR3). According to that, we will calculate the reciprocal value of the debt ratio $\left(1 / \mathrm{Y}_{3}\right)$. In that way, we will create decision matrix only with benefit criteria (max), all six of them.

Table 5:

\section{CALCULATION OF 6 BENEFIT CRITERIA}

\begin{tabular}{|c|c|c|c|c|c|c|c|}
\hline No & COMPANY & CR1 - NET PROFIT MARGIN & CR2 - RETURN ON ASSET & CR3 - RECIP. VALUE OF DEBT RATIO & CR4 - INTEREST COVERAGE RATIO & CRS - CURRENT RATIO & CR6 - RECEIVABLES TURNOVER \\
\hline 1 & INA GROUP & $0,61 \%$ & $2,99 \%$ & $209,30 \%$ & 2,41 & 0,76 & 10,20 \\
\hline 2 & HEP GROUP & $15,76 \%$ & $6,94 \%$ & $285,35 \%$ & 7,45 & 1,65 & 7,49 \\
\hline 3 & HT GROUP & $13,31 \%$ & $8,57 \%$ & $600,29 \%$ & 8,60 & 3,01 & 5,42 \\
\hline 4 & PLIVA Ltd & $17,18 \%$ & $11,22 \%$ & $255,03 \%$ & 4,16 & 1,05 & 2,88 \\
\hline 5 & PLODINEPIC & $2,21 \%$ & $5,38 \%$ & $121,75 \%$ & 1,95 & 0,42 & 53,99 \\
\hline \multicolumn{2}{|c|}{ objective function: } & $\max$ & $\max$ & $\max$ & $\max$ & $\max$ & $\max$ \\
\hline \multicolumn{2}{|r|}{ criterion: } & $Y_{1}$ & $Y_{2}$ & $1 / Y_{3}$ & $Y_{4}$ & $Y_{5}$ & $Y_{6}$ \\
\hline & TOTAL: & $49,07 \%$ & $35,10 \%$ & $1471,72 \%$ & 24,58 & 6,89 & 79,99 \\
\hline
\end{tabular}

Source: Created by the authors.

\section{Step 4 - Transformation of 6 benefit criteria}

After we created a positively oriented decision matrix (which includes all benefit criteria) we can proceed with percentage transformation of each criterion. This transformation includes the values of criteria between 0 and 1 according to the following relation (Sawaragi, Nakayama, Tanino, 1985):

$$
r_{i j}=\frac{Y_{i j}}{\sum_{t=1}^{5} Y_{i j}} \text { where is } i=1,2,3,4,5 \text { for the companies and } j=1,2,3,4,5 \text {, }
$$

6 for criteria.

For each column i.e. value of criterion, total of values should be equal to one. 
Table 6:

PERCENTAGE TRANSFORMATION OF 6 BENEFIT CRITERIA

\begin{tabular}{|c|c|c|c|c|c|c|c|}
\hline No & COMPANY & CR1 - NET PROFIT MARGIN $\left(\eta_{1}\right)$ & $\mid$ CR2-REURN ONASSE (E) & (CF3-RECIP. VALUE OF DEBT RAT10(5) & | CRA- INTREEST COVERAGE RATIO(E) & |CRS- CURRENT RAT10|55) & CRf - RECEVIABBLE TURNOVER $\left(F_{5}\right)$ \\
\hline 1 & INAGBOUP & 0.124 & 00052 & & & & \\
\hline 2 & HEP GROUP & 0,3212 & 0,1978 & 0,1939 & 0,3030 & 0,2391 & 0,0936 \\
\hline 3 & HT GROUP & 0,2713 & 0,2442 & 0,4079 & 0,3501 & 0,4374 & 0,0677 \\
\hline 4 & PLIVA LItd & 0,3501 & 0,3196 & 0,1733 & 0,1694 & 0,1527 & 0,0361 \\
\hline 5 & PLOOINEPIC & 0,0450 & 0,1532 & 0,0827 & 0,0755 & 0,0611 & 0,6750 \\
\hline & ective function: & $\max$ & $\max$ & $\max$ & $\max$ & $\max$ & $\max$ \\
\hline & crittrion: & $Y_{1}$ & $Y_{2}$ & $1 N_{3}$ & $Y_{4}$ & $Y_{5}$ & $Y_{6}$ \\
\hline & TOTAL: & 1,0000 & 1,0000 & 1,0000 & 1,0000 & 1,0000 & 1,0000 \\
\hline
\end{tabular}

Source: Created by the authors.

\section{Step 5 - Forming of comparison matrix}

In this model criteria are ranked according to their importance (Saaty's scale of relative importance) as follows (Saaty, 1980). The first group of criteria (CR 1 \& CR 2) includes profitability ratios as the most important ratios in this model. The second group of criteria (CR 3 \& CR 4) includes solvency criteria that are less important than the first group. Finally, the third group of criteria consists of one criterion (CR 5) from the liquidity group and one criterion (CR 6) from the activity group which are least important in this model. Within the problem of decision making, not all the criteria are usually equally important and the relative importance of criteria is derived from the preferences of the decision maker, i.e. authors of the article in this case. Anyone else could group criteria differently and express some other preferences as a decision maker.

The criteria are compared in pairs relative to how many times one is more important than the other for achieving the set goal (by using a ratio scale). The comparison matrix $A$ is formed with elements $a_{i j}$, which represent the numerical preference of criterion $i$ over criterion $j$. This matrix is positive and the matrix elements are positive numbers. In addition, it is also true that $\mathrm{a}_{\mathrm{ij}}=1 / \mathrm{a}_{\mathrm{ij}}$ for each pair of indices $(i, j)$. After this, it is examined whether this matrix is consistent, and if not, the consistency index is determine. For comparison matrix $A=\left(a_{i j}\right)$ it can be said that it is consistent if $\mathrm{a}_{\mathrm{ij}}=\mathrm{a}_{\mathrm{ik}} \times \mathrm{a}_{\mathrm{kj}}$ for each $(i, j, k)$. If the matrix is consistent, its elements are ratios of relative importance of weights $(W)$, and $a_{i j}=W_{i} / W_{j}$. Alternatives are compared to each other in pairs for each of the criteria, assessing 
the extent to which one of the criteria is given an advantage compared to the other. A series of matrices is formed and used to compare alternatives for each criterion separately, as shown in Table 7 (Saaty, 1990).

Table 7:

COMPARISON MATRIX A

\begin{tabular}{|c|c|c|c|c|c|c|}
\hline AHP & CR1-NPM & CR 2-ROA & CR 3-DR & CR 4 - ICR & CR 5- CR & CR 6-RT \\
\hline CR 1 & 1 & 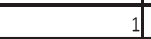 & 2 & 2 & & \\
\hline CR 2 & & 1 & 2 & 2 & 4 & \\
\hline CR 3 & 0,5 & 0,5 & 1 & 1 & 2 & \\
\hline CR 4 & 0,5 & 0,5 & 1 & 1 & 2 & \\
\hline CR 5 & 0,25 & 0,25 & 0,5 & \begin{tabular}{l|l}
0,5 \\
\end{tabular} & 1 & \\
\hline CR 6 & 0,25 & 0,25 & 0,5 & 0,5 & & 1 \\
\hline & & & & & & \\
\hline TOTAL & 3,5 & 3,5 & 7 & 7 & 14 & 14 \\
\hline
\end{tabular}

Source: Created by the authors.

\section{Step 6 - Calculation of local priorities}

After defining the comparison matrix A, we should calculate local priorities, i.e. weights of each criterion in the model (Saaty, 1990). If we divide elements from the first column in the comparison matrix A by total sum for that column, i.e. criterion (Table 7), we will get a value of weights for that criterion. If we repeat that calculation for each column in the comparison matrix A, we will get the same result for weights for all six criteria, as shown in Table 8. Finally, total value of all weights for selected criteria in the model should be equal to one $\left(\mathrm{W}_{1}+\mathrm{W}_{2}+\mathrm{W}_{3}+\right.$ $\left.\mathrm{W}_{4}+\mathrm{W}_{5}+\mathrm{W}_{6}=1\right)$. 
Table 8:

CALCULATION OF WEIGHTS

\begin{tabular}{|c|c|c|c|c|c|c|c|c|}
\hline AHP & $W_{1} \cdot C R 1$ & $W_{2} \cdot C R 2$ & $W_{3} \cdot C R 3$ & $W_{4}=C R 4$ & $W_{5}-C R 5$ & $W_{6}=C R 6$ & 3 & \\
\hline CR 1 & 0,28571429 & 0,28571429 & 0,28571429 & 0,28571429 & 0,28571429 & 0,28571429 & 0,286 & $W_{1}$ \\
\hline CR 2 & 0,28571429 & 0,28571429 & 0,28571429 & 0,28571429 & 0,28571429 & 0,28571429 & 0,286 & $\mathrm{~W}_{2}$ \\
\hline CR 3 & 0,14285714 & 0,14285714 & 0,14285714 & 0,14285714 & 0,14285714 & 0,14285714 & 0,143 & $W_{3}$ \\
\hline CR 4 & 0,14285714 & 0,14285714 & 0,14285714 & 0,14285714 & 0,14285714 & 0,14285714 & 0,143 & $W_{4}$ \\
\hline CR 5 & 0,07142857 & 0,07142857 & 0,07142857 & 0,07142857 & 0,07142857 & 0,07142857 & 0,071 & $W_{5}$ \\
\hline CR 6 & 0,07142857 & 0,07142857 & 0,07142857 & 0,07142857 & 0,07142857 & 0,07142857 & 0,071 & $\mathrm{~W}_{6}$ \\
\hline TOTAL & 1,000 & 1,000 & 1,000 & 1,000 & 1,000 & 1,000 & 1,000 & \\
\hline
\end{tabular}

Source: Created by the authors.

\section{Step 7 - Results of AHP method}

Final results represent the Score $\left(\mathrm{S}_{\mathrm{i}}\right)$ of the selected companies $(i=1,2,3,4$ and 5) with selected criteria and obtained weights calculated from the following relation (Saaty, 2008):

$$
\mathrm{S}_{\mathrm{i}}=\mathrm{r}_{\mathrm{i} 1} \times \mathrm{W}_{1}+\mathrm{r}_{\mathrm{i} 2} \times \mathrm{W}_{2}+\mathrm{r}_{\mathrm{i} 3} \times \mathrm{W}_{3}+\mathrm{r}_{\mathrm{i} 4} \times \mathrm{W}_{4}+\mathrm{r}_{\mathrm{i} 5} \times \mathrm{W}_{5}+\mathrm{r}_{\mathrm{i} 6} \times \mathrm{W}_{6}
$$

Accordingly, we will get the total priority for each company $\left(\mathrm{S}_{\mathrm{i}}\right)$ and we can do the comparison between companies. The total value of each Score $\left(\mathrm{S}_{\mathrm{i}}\right)$ should be equal to one.

For example, Score $\left(\mathrm{S}_{4}\right)$ for the company PLIVA Ltd is equal to:

$$
\begin{aligned}
\mathrm{S}_{4}= & \mathrm{r}_{41} \times \mathrm{W}_{1}+\mathrm{r}_{42} \times \mathrm{W}_{2}+\mathrm{r}_{43} \times \mathrm{W}_{3}+\mathrm{r}_{44} \times \mathrm{W}_{4}+\mathrm{r}_{45} \times \mathrm{W}_{5}+\mathrm{r}_{46} \times \mathrm{W}_{6} \\
\mathrm{~S}_{4}= & 0.3501 \times 0.286+0.3196 \times 0.286+0.1733 \times 0.143+0.1694 \times 0.143+ \\
& +0.1527 \times 0.071+0.0361 \times 0.071=0.253766
\end{aligned}
$$


Table 9:

\section{SCORES OF AHP METHOD}

\begin{tabular}{|c|r|}
\hline \multicolumn{2}{|l|}{ RESULTS OF AHP METHOD (TOTAL PRIORITY FOR EACH COMPANY): } \\
\hline COMPANY 1 - INA GROUP & 0,079166 \\
\hline COMPANY 2 - HEP GROUP & 0,243012 \\
\hline COMPANY 3 - HT GROUP & 0,291646 \\
\hline COMPANY 4 - PLIVA Ltd & $\mathbf{0 , 2 5 3 7 6 6}$ \\
\hline COMPANY 5 - PLODINE PIC & $\mathbf{0 , 1 3 2 4 1 0}$ \\
\hline TOTAL & 1,000000 \\
\hline
\end{tabular}

Source: Created by the authors.

\section{Step 8 - Final ranking of the companies}

The final ranking of companies is shown in descending order, with the company with the highest Score being the best ranked (Zeleny, 1982). In this case, HT group is the company with the highest Score and INA group has the lowest Score.

Table 10:

FINAL RANKING IN THE MODEL

FINAL RANKING (DESCENDING RANKING OF THE COMPANIES):

\begin{tabular}{|c|c|c|c|}
\hline No & COMPANY & RESULT & PD \\
\hline 1 & HT GROUP & 0,291646 & 0,59993354 \\
\hline 2 & PLIVA Ltd & 0,253766 & 0,68948813 \\
\hline 3 & HEP GROUP & 0,243012 & 0,72000000 \\
\hline 4 & PLODINE PIc & 0,132410 & 1,32141620 \\
\hline 5 & INA GROUP & 0,079166 & 2,21013307 \\
\hline \multicolumn{2}{|c|}{ TOTAL } & 1,000000 & \\
\hline
\end{tabular}

Source: Created by the authors. 
Starting point in Step 8 is HEP group as the only one which has external credit rating "BB" (Standard \& Poor's) and in transition matrix, this credit rating has the value of PD equal to $0.72 \%$. Using the mathematical proportion, we can get PD values for four other companies, that do not have external credit ratings of their own but have results (Scores) according to the internal model based on AHP method.

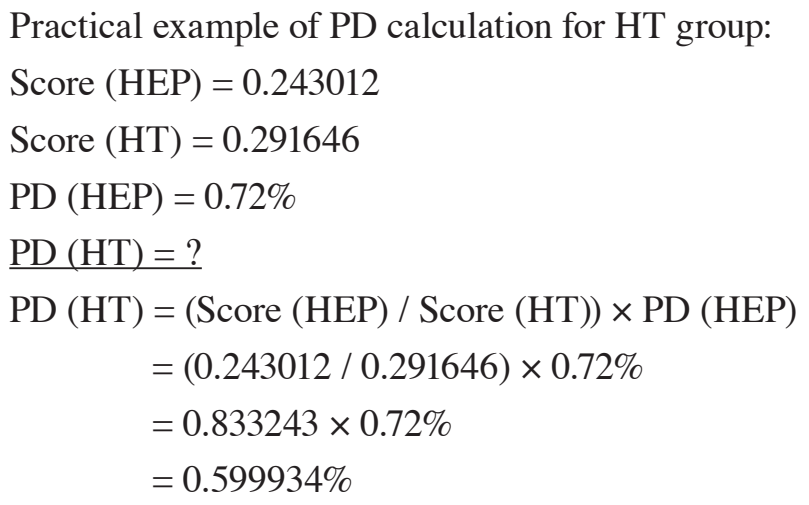

\section{Step 9 - ECL calculation}

Finally, we can show a research example of ECL variable calculation which includes EAD, LGD and PD parameters:

Our company has sold merchandise to PLODINE Plc. and has receivables in the amount of 5,000,000 HRK. There is no collateral. PD of counterparty (PLODINE) is determined in step 8 and it equals $1.321 \%$. We will calculate 12-month ECL which is in case of receivables the same as lifetime ECL.

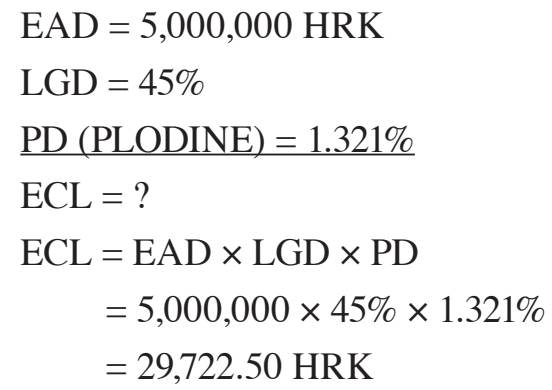

Expected credit losses are 29,722.50 HRK and should be posted in P\&L as the impairment expense, and also in Balance sheet as value adjustment for the receivables. 


\section{IT support}

The implementation of IFRS 9 is impossible without adequate IT support. For bigger business entities that have their own IT departments, the cheapest solution would be to develop their own in-house IT solution (ECL-IT). The alternative, of course, is to buy a ready software. In both cases, ECL-IT needs to be interfaced to the accounting IT solution (ACC-IT) and to the Treasury \& Risk management IT solution (TRE-IT). Preparation and configuration of ECL-IT needs to be done by the Accounting Department in close cooperation with the Treasury and Risk management departments. ECL needs to be calculated for each reporting date, at least annually for the reporting date 31 December, but it is advisable to calculate ECL monthly for the purpose of true and fair internal financial reporting.

ECL-IT will import the amounts related to financial instruments from ACCIT and calculate variable EAD (including the accrued interest). Risk management and Treasury should determine and do the input of values of LGD (for collateral) and PD for the counterparties. Having all three variables, the ECL-IT will perform an ECL calculation. ECL-IT has to transform the ECL calculation into a posting transaction to be exported to ACC-IT. It has to be booked analytically on the level of each financial instrument. Each new ECL calculation has to take into account the previous ECL calculation for the same financial instrument, so the posting transaction in P\&L should be only the difference. In case the next ECL calculation is done for a financial instrument that has been sold or matured meanwhile (derecognition), then ECL-IT should produce a different posting transaction in favor of revenue. In-built internal IT control should ensure that ECL-IT calculates ECL only for "live" financial instruments, still presented in Balance sheet. Before the validation of these bookings, the Risk management and Treasury should carry out control and make the authorization of used variables and calculated ECL. Consequently, ECL-IT should have various groups of users having different kind of roles (user rights).

\section{Conclusion}

As announced in the introductory section, this article offers a solution for implementing the most difficult part of new IFRS 9 i.e. the development of internal model for calculation of Expected Credit Losses for financial instruments. The article contains both theoretical and practical instructions for defining, determining and computing all three variables in the ECL formula: Exposure at Default (EAD), Loss Given Default (LGD) and Probability of Default (PD). 
Variable EAD is an accounting amount, it is either nominal or amortized value plus accrued interest. Determination of the LGD variable, in absence of detailed stipulation in IFRS 9, is borrowed from the Basel's Capital Requirements Regulations, and it distinguishes whether there is collateral received or not (Regulation EU No 575/2013). The authors propose Analytic Hierarchy Process (AHP) as an appropriate mathematical technique for calculating the third, crucial variable - PD.

The creation of such mathematical decision making problem starts with the selection of criteria, in this case known as financial indicators (Horngren, Oliver, 2010), from basic financial statements of the selected companies (selected from the list of the ten biggest entrepreneurs in the Croatian business sector according to total revenues in 2016). Criteria are attributes which describe the success and safety of the company's business and their purpose is to provide information about achieving a desired goal. The main objective of such multi criteria decision making problem is to create a list of ranked companies with a specific score which is mathematically related to the calculation of PD variable. The minimum requirement for the use of this model is the existence of at least one company, in the list of the selected companies, with the defined credit rating from the external rating agency (in this case, Standard \& Poor's). The created internal model can be solved by MS Excel, which gives a possibility of a user friendly appliance.

It should be pointed out that the solution described is simplified but tested in practice and that it is compliant with all the requirements of IFRS 9. Many business entities, including commercial banks and similar financial organizations, may find it useful. However, they need to approach this issue in a more complex way.

\section{LITERATURE}

Atrill, P., McLaney, E. (2006). Accounting and Finance for Non-Specialists. Harlow. Prentice Hall, 5th edition.

Bank for International Settlements, Basel Committee on Banking Supervision (2015). Guidance on credit risk and accounting for expected credit losses, ISBN 978-929197-387-3, www.bis.org

Blocher, E., J., Chen, K., H., Lin, T., W. (2002). Cost Management: A Strategic Emphasis. New York: McGraw-Hill/Irwin.

Commission Regulation (EU) 2016/2067 of 22 November 2016 amending Regulation (EC) No 1126/2008 adopting certain international accounting standard sin accordance with Regulation (EC) No 1606/2002 of the European Parliament and of the Council as regards International Financial Reporting Standard 9 - Annex "IFRS 9 Financial Instruments”, Official Journal of the European Union 29.11.2016. 
EBA, (2017). Guidelines on credit institutions credit risk management practices and accounting for expected credit losses, EBA / GL / 2017 / 06, http://www.eba.europa.eu/ documents/10180/1842525/Final+Guidelines+on+Accounting+for+Expected+Credi $\mathrm{t}+$ Losses+\%28EBA-GL-2017-06\%29.pdf

Ehrgott, M., Klamroth, K., Schwehm, Ch. (2004). An MCDM approach to portfolio optimization. European Journal of Operational Research, Vol. 155, pp. 752-770.

EY (2014). Impairment of financial instruments under IFRS 9, www.ey.com

EY (2015). Classification of financial instruments under IFRS 9, www.ey.com

Finance Trainer International Ges.m.b.H, ALMForum (2016). "Impacts of IFRS 9 on the accounting of financial instruments", No. 16, September 2016, Wien.

Grant Thornton (2016). Get ready for IFRS 9 - The impairment requirements, www.grantthornton.global

Horngren, C., T., Oliver, M., S. (2010). Managerial Accounting. New Jersey: Upper Saddle River, Pearson Prentice Hall.

KPMG (2016). Guide to annual financial statements: IFRS 9 - Illustrative disclosures for banks, www.kpmg.com/ifrs

KPMG (2017). Demystifying Expected Credit Loss (ECL), https://alumni.in.kpmg.com

PWC (2015). A look at current financial reporting issues - IFRS 9: Classification, measurement \& modifications - Questions and answers, www.pwc.com

PWC (2017). IFRS 9 for banks - Illustrative disclosures, www.pwc.com

Regulation (EU) No 575/2013 of the European Parliament and of the Council of 26 June 2013 on prudential requirements for credit institutions and investment firms and amending Regulation (EU) No 648/2012, Official Journal of the European Union 27.06.2013.

Saaty, T.L. (1980). The Analytic Hierarchy Process: Planning, Priority Setting, Resource Allocation. New York: McGraw-Hill.

Saaty, T.L. (1990). "How to make a decision: The Analytic Hierarchy Process". European Journal of Operational Research, Volume 48, Issue 1, Pages 9-26, September 1990.

Saaty, T.L. (2008). "Decision making with The Analytic Hierarchy Process". International Journal of Services Sciences, Volume 1, Pages 83-98, January 2008.

Sawaragi, Y., Nakayama, H., Tanino, T. (1985). Theory of Multiobjective Optimization. Orlando: Academic Press, Inc.

Spratings.com, (2016), Default, Transition, and Recovery: 2016 Annual Global Corporate Default Study And Rating Transitions, https://www.spratings.com/documents/2018 4/774196/2016+Annual+Global+Corporate+Default+Study+And+Rating+Transitio ns.pdf/2ddcf9dd-3b82-4151-9dab-8e3fc70a7035

Standard \& Poor's, (2017). Default, Transition and Recovery: 2016 Annual Global Corporate Default Study and Rating Transitions, www.standardandpoors.com/ratingsdirect

Streitenberger, M., Miloš Sprčić, D. (2011). „Prediktivna sposobnost financijskih pokazatelja u predviđanju kašnjenja u otplati kredita”. Economic Review, Volume 62, No. 07-08, Pages 383-403, September 2011. 
Topp, R., Perl R. (2010). “Through-the-Cycle Ratings Versus Point-in-Time Ratings and implications of the Mapping Between Both Rating Types". Financial Markets, Institutions \& Instruments, Volume 19, Issue 1, Pages 47-61, February 2010.

Zeleny, M. (1982). Multi criteria decision-making. New York: McGraw-Hill.

\section{INTERNI MODEL ZA MSFI 9 - KALKULACIJA OČEKIVANIH KREDITNIH GUBITAKA}

\section{Sažetak}

Ovaj članak istražuje i analizira problem implementacije međunarodnog standarda financijskog izvještavanja 9 (MSFI 9) koji je u primjeni od 1. siječnja 2018. godine. MSFI 9 je najrelevantniji za financijske institucije, ali i za sve ostale poslovne subjekte koji imaju značajan udjel financijske imovine u svojoj bilanci. Glavni cilj ovog članka je implementacija novog modela umanjenja vrijednosti za financijske instrumente što se iskazuje mjerenjem očekivanog kreditnog gubitka (ECL). Primjena ovakvog modela je u korelaciji s kreditnim rizikom poduzeća za što je potrebno utvrditi njegove osnovne varijable kao što su to izloženost riziku nevraćanja kredita (EAD), postotak mogućeg gubitka (LGD) i vjerojatnost nevraćanja kredita (PD). Za izračun LGD-a može se koristiti Baselska regulativa, dok se izračun PD-a zasniva na specifičnoj metodologiji kod koje postoje dvije različite opcije. Prva varijanta nudi korištenje eksternih podataka o PD-u od strane pouzdanih rejting agencija. Kada ne postoji vanjski rejting, treba razviti interni model kojim se izračunava PD. U cilju razvoja internog modela autori članka predlažu primjenu modela višekriterijskog odlučivanja temeljenog na metodi analitičkog hijerarhijskog procesa (AHP). Obrada ulaznih podataka u modelu se bazira na podacima iz financijskih izvještaja, dok se za izračun ovakvog višekriterijskog problema koristi MS Excel. Rezultati internog modela matematički se povezuju s vrijednostima PD-a za svako analizirano poduzeće. Jednostavna implementacija ovog internog modela daje mu prednost u odnosu na druge puno kompleksnije modele.

Ključne riječi: MSFI 9, očekivani kreditni gubici (ECL), izloženost riziku nevraćanja kredita (EAD), postotak mogućeg gubitka (LGD), vjerojatnost nevraćanja kredita (PD), analitički hijerarhijski proces (AHP), interni model. 